\title{
The Teachers Experience of Practice-BASEd EDUCATION IN HYBRID DELIVERY MODE
}

\author{
Felicity Molloy PhD MEd GDHE \\ Independent Academic, Auckland, New Zealand
}

\begin{abstract}
Rapid eLearning implementation at a New Zealand-based natural therapies' college provides space for academic reflection. The aim is to utilise a formative assessment to explore hybrid-delivery through practitioner-educator and somatics lenses. Somathodology, an experiential methodology binds a triquetra of themes and theories, generating memory and reflections of experiencing pedagogy, and where eLearning situates experienced practitioner-come-educators at the border of their field of enquiry. I engage with the methodology to write first-person research. Social theories focus the account on embodied work. Journal writing and imaginary letters are criticality devices; what Laurel Richardson describes as the $5^{\text {th }}$ kind of narrative. Evidence-based healthcare is compared with naturopathy care. Novel insights are discussed about how somatic attributes of awareness, breathing, and listening signal an emerging trend for disciplinary connection, and autonomous identity. Naturopathy clinical education in an eLearning setting become embodying sites of co-construction and livestream formative process, a critical pedagogical event.
\end{abstract}

\section{KEYWORDS}

Practice-based education, Hybrid pedagogy, Somatics.

\section{INTRODUCTION}

So long as the work of education is not clearly institutionalized as a specific, autonomous practice, so long as it is the whole group and a whole symbolically structured environment, without specialized agents or specific occasions, that exerts an anonymous, diffuse pedagogic action, the essential part of the modus operandi that defines practical is transmitted through practice, in the practical state, without rising to the level of discourse (Bourdieu, 1990, pp. 7374).

Shifts to livestream classrooms are more than a sustainability choice for naturopathy education. As "our science [natural therapies so far] is open-ended, unruly, disruptive" (MacLure, 2006 and cited in Denzin, 2013, p. 355), I am reliant on criticality without the use of empirical data, and for subsequent unruly research methods - "complicating, disconcerting ways of engaging and representing educational scenes" (MacLure, 2006, p. 10). There are few studies that consider impacts of eLearning on an emergent practice-based field of enquiry such as naturopathy.Even by the millennium's second decade, New Zealand natural therapies colleges offering tertiary qualifications, experience of off-campus education is limited. There are few established models to work from.By making somatics a recognizable educational discourse, I have initiated a less explored I-laden, self-making experience with potential for richer meaning-making of I-laden self-making experiences of academics - the collective beyond those who are natural therapists (Molloy, 2021). 
The aim of this article is to somatically position practitioner-educator experience of hybrid delivery within aqualitative descriptive approach that meets the enquiry purpose. This approach is less reliant on researcher interpretation repertoires(Kim, Sefcik, \&Bradway, 2017; Sandelowski, 2010), and more on abstract depictions of embodied professional experience bound in a methodological triquetra of themes and theories.Somathodology, an experiential methodology, generates contexts for memory and reflections of experiencing pedagogy (Molloy, 2016), and where eLearning situates experienced practitioner-come-educators at the border of their field of enquiry. I engage with somathodology to write about a long-term practitioner educator experienced in a range of marginalised or emerging academic fields in a first-person research standpoint. Social theories focus the account on embodied work. Journal writing and imaginary letters are criticality devices; what Laurel Richardson (2000) describes as the $5^{\text {th }}$ kind of narrative.

The basis of this article, therefore, is first placed in context with WHO Traditional Medicine (WHO-TM) Strategy, 2014-2023. The strategy responded to the World Health Assembly resolution on traditional medicine (WHA62.13) - to promote "the safe and effective use of TM by regulating, researching and integrating TM products, practitioners and practice into health systems, where appropriate" (2010, p. 11 [my italics]). Each theme and theory is drawn on to expand Dewey's connections of embodying pedagogy - to embodiment in clinical practice (Acolin, 2019; Koch, 2014).Taken together, concepts of gesture, body feedback, identity, sociality, and spatiality are all apt to help explain contextual spaces of embodimentandmake meaning of alternative disciplines of naturopathy practitioner teaching.

The central question the aim raises is about how a somatically informed approach to eLearning supports practitioner educator pedagogy. The recent venture into hybrid delivery at a New Zealand-based institution is reflected on, thus, as experiential. Formative assessment of a research and critical thinking course is explored as practice-based education in hybrid delivery mode. Embedded descriptions about how the institution came to employ technology, and challenges that educators resolved provide entry points to explore diffuse pedagogical links between practitioner educator experience, clinical practice and emerging benefits of technology in practitioner classrooms. Arguably, the destabilisation of naturopathy's education curriculum through technology becomes a prompt to reduce disciplinary opacity and enhance competencies.

Disciplining methodological intersections of overarching themes played out as initial assumptions, and social theories focus a reflexive account of somatics at work in practitioner education. Themes are based on three assumptions:Somatics is a reflexive way of understanding applications of embodiment, Practitioner education is embodied, and autoethnography helps explain that, and on terms of transdisciplinarity: naturopathy education is not like medical science education.Social contexts of bodies being onsite and others being 'over there or elsewhere' (offsite) are also connected to Dewey's embodied pedagogy where the teacher's body is agential of salient characteristics ofclinical practice (Nguyen \& Larson, 2105). These characteristics may be further discussed as attainment of relevant attributes for the discipline. Each theme, once discussed through an autoethnographic lens, gives rise to social theories of the body, identity and practice that help extricate ways to interpret somathodology' themes. Taken together, the theories produce questions about how bodies become first disembodied by online location, and in exchange, how bodies are restored by on- and off-site communication and collaboration.

Theorising supports a reflexive methodology (Alvesson, \&Sköldberg, 2009). From theorising emerges the article's third motivation, pedagogical enhancement with eLearning; refreshed practitioner-educator purpose. This is how I think of Richardson's description of the " 5 th $k$ kind of narrative" (1997, p. 32). And in turn, through concepts of diffuse pedagogy (Claussen \& Osborne, 2013), integral to the experience of teaching in a newly enhanced delivery style, I explore constructivist dimensions of resistance and resolution as provision, practice dispositions 
marking them as likely attributes of naturopathy practitioners. Here are identities that are less like those produced by the evidence-based model of healthcare education. Larson (1977) claims that specialisation and creation "of 'bodies' of practice or theoretical knowledge are a function of the accumulation of resources" (p. 2, my "). In brief, resolving technological obstacles become practice resources and, potentially, an observable unique professional capability in a marginalised profession.

A triplet of responses to the methodological aim plays out in the practitioner-educator motivation for teaching with powerful technologies to the embodiment of adaptive collaboration in communication modes (Bell, Canham, Dutta, \& Fernández, 2020). I-experiencing strategies shift the article's focus from studying students, to an autoethnographic retroactive witnessing, and insights about teacherly process are highlighted by the theories. Journal writing as a means for research reflection was inspired by another academic exercise. This article' length precludes long explanations about the joys of writing and journaling at Tauhara Retreat Centre, Taupo, New Zealand, but for glimpses into the inspirational interludes, read Grant and Knowles (2004). I have been attending them since 2007. Similarly, imaginary letters are created as criticality devices to remember and reflect experience. By incorporating somatic principles for studying first-person experience - qualitative, related aspects of 'experience' and self in professional work, become requisite of pedagogical intention and interactive classrooms, transformative and symbolic of an enacted habitus.

\section{Somathodology}

Somathodology, a unique experiential methodology bound by overarching themes and theories, is generated to reflect on practitioner pedagogy. Somathodology is adaptive and already formed in higher education. In my doctoral thesis, I utilized the mathematical theorem of Borromean rings and its triquetra form to explore layered meanings in theories and data, to manage the analytical flow of embodied themes, and integrate reflections throughout the research process (Molloy, 2016). Here, I engage with somathodology for writing first-person research, and social practice theories to focus an account of embodied teaching. Autoethnographic journal writing, and imaginary letters are criticality devices to remember and reflect experience about a marginalised group of healthcare practitioners. While the integration of technology is particularly challenging in practice-based disciplines, comparing practitioner-educator experience with online delivery is reflexively pertinent to an emerging field.

Theories, integrated within the practitioner/educator narrative and provide teaching inferences that align somatic modes of attention with embodied clinical practice (Csordas, 1980; Hargreaves, 2000). That is, theoretical emphases of body, identity and practice are embodied in attention: listening, awareness of transition when breathing, and immediacy. In somatic mode, assumptions are explored about how people teach and attend to the academy. As embodied attributes of communication and collaboration identity, practice and bodies are informed by clinical practice in academia and, more significantly through the technological ether, inform the embodiment theme (Green \& Johnson, 2015). As previously mentioned, somatics is positioned as a central epistemology to explain the complexity of bodies and selves in tertiary education, not just in acts of teaching, but also as in listening and breathing. Methodologically, the theories become tripartite axes for apprehension of immediacy in thematic interpretive torsion. Consequentially, reflexivity is based on insights emerging from the experience of teaching in the space of eLearning.

\subsection{Somatic eLearning: Breathing in the experience and breathing out the discipline}


Breathing simply happens and happens and happens (Leder, 1990, p. 171).

Somatics is a reflexive way of understanding applications of embodiment. In the following journal excerpt, observing visceral withdrawal and breath changes, as anxiety about technology surfaced, became physiological indicators of pedagogical enaction. With somatic modes of attention and simultaneous conscious breathing, there comes about a repetitive and calming stimulus or tolerance of external environment (Tihanyi, Ferentzi\&Köteles, 2017). I felt breathing in teaching practice enhanced the curriculum and, curiously, the sense of a profession.

The spotlight of reflection turns inwardly to what I was thinking and feeling and as, with the medium of technology to navigate, there was little time during the sessions to reflect. My anxieties, already symptomatic of a generational somewhat disembodied literacy, are exacerbated by complexities of newly implemented technologies. In close dialogue with students both on- and off campus in each session, the benefits and challenges of technology were shared. When teaching, I noticed how I leant forward, my gut churned with nerves each time we turned technology on, I noticed how I tilted my head to ensure they (the students) were aware that I was listening with purpose, and as they spoke, I breathed consciously in time with the pace and flow of their presentation to reduce (mine) and the students' nerves. Even thinking about how our breath patterns are an example of exchange, I experienced an increased confidence in embodied pedagogy. This reassurance is emotive yet focussed as teaching and in the context of reflexivity has developed from these livestream contexts as much as content delivery (Teacher journal, Tauhara, 2018).

I align the immediacy of resolving technology challenges with emerging practitioner attributes of deep and empathic knowledge. Eventually in clinic settings, experiential practices of presence: breathing and awareness are inseparable from effective practitioner-client communication (Paul, Elam \& Verhulst, 2007). "Moment-to-moment breathing actualises our one-body relation with the surrounding world" (Leder, 1990, p. 171). What is made relevant to consciously aligning breath rhythm with the needs of students to manage their nerves, becomes relevant to clients learning more about how to care for themselves. Making our way through assessment and technology issues in somatic mode, focus practitioner concepts on identity and embodied development to be embedded in the curriculum.

\subsection{Taking somatic awareness and reflexivity into account}

Somatics, introduced into the reflexive process, produce a notion that practitioner-educators may be practice enabled by having to adapt to technology in classrooms. Teachers have become more skilled in less conventional, integrated educational practices that enhance the "certain direction of development in human beings" (Shor, 1999). I explore practice values through a somatic lens to capture an embodied social presence, relevant to clinical practice. Through addressing technological capability issues, practitioner values of collaboration and responsivity surface as integral to professional capability. Consequent of the given - tactile and spatial familiarity of interactive presentation, engagement in kinaesthetic awareness through technology produces deep engagement (empathic) and better accommodation of spatial awareness. Martin (1992) claims no such distinction outside of experience. It is more a shift in attention from the bodily side of proprioception to the exteroceptive site of perceptual experience. These are practitioner attributes in clinical mode.

I noticed how students took up a practice position in their presentations, accommodating comfort and stillness even for a few moments. Somatic approaches to embodied learning are not so much to incorporate yet another 'alternative' remedy but to reposition us in the practitioner education 
discourse. I have already noticed how much more readily evidence-based terms and concepts flow in our discussions. (Teaching journal, Tauhara, 2018)

Challenging communication, technological issues with audio, or unusual variances in the expected pace of learning are highlighted. By drawing on somatic practices of breathing and listening in awareness, embodied experience becomes a vehicle for perceiving natural therapies pedagogy undergoing change. Somatics are introduced as a theoretical system when studying bodily awareness as a knowledge resource (Eddy, 2002; Ginot, Barlow \& Franko, 2010). It is my researcher emphasis on an internally focused body rather than an externally focused pedagogically content body-of-knowledge that leads to ongoing reflection about whether a perceived division between curriculum delivery and technology makes somatics an important educative practice, and important to clinical care.

\section{Auto ETHNOGRAPHY: RETROACTIVE WitNESS OF THE 5TH KIND OF NARRATIVE}

Overall, teachers for the livestream classrooms were excited. As experienced educators, they are fluent with course content and holistic connections across the entire programme. The physical restraints and limitations of familiar teaching practices come to the fore of our discussions. I am not used to being free of the lectern. I prefer to walk around the classroom. Additional paraphernalia of microphones and headgear is something familiar, performance shyness. While academic and IT staff members focussed as a new team, it is apparent that technology knowhow is about managing classrooms, access and good communication is needed to facilitate specific learning needs for us practitioner/educator. (Teacher journal, Tauhara, 2018)

By mulling over this reflection, I see how efforts to discern how to adapt clinical education to technology environments becomes an embodying site of co-construction and livestream formative process, a critical pedagogical event. Practitioner education is already embodied and autoethnography helps explain that. I make use of autoethnographic readings to draw out this reflexively rich resource for thinking about practice-based clinical education. I utilise what Laurel Richardson (1997, p. 32) describes as the ' 5 th kind of narrative' for writing first-person research with journal assemblages prompting an unusual writing gambit. Two imaginary letters to my parents with their equally imaginary responses help me recall connections I make between the initial purposes for eLearning and, from the potential for adaptation from session to session - as in how we adapted to the new mode (Ellis, Adams, \&Bochner, 2010). By reflectively drawing on $5^{\text {th }}$ persons through a somatic educator lens, and attendant on formative assessment, technological implementations re-contextualised are readymade for clinical applicationwith disciplinary capabilities capable of integration.

Hybrid delivery impelled change to the traditional onsite classroom structure and, through smartboard technology, more than one simultaneous learning option, F2F and off-campus students. Smartboard technology meant that the teacher could see and hear all students present in class. Teachers with moderate levels of techno savvy operated a laptop for chat and split screen PowerPoint/whiteboard. In keeping with normal modes of online learning, and arguably "increased flexibility in time, place and pace" (Morgan \& Bird, 2007, p. 248), real-time sessions were recorded and uploaded within a few hours. All students enrolled in a course had access to the recorded material. To keep up with curriculum content and sequence if they missed a scheduled class, students were advised to watch the recording no more than 24 hours after the actual classroom time. Summative tests and practice-based assessments were largely conducted during term-by-term block intensives, although assessment presentations remained in their usual format - on campus only during intensives prior to term recess.(Teacher journal, Tauhara, 2018) 
Autoethnographic writing is a way of unpacking teaching from experiencing and, thus, embodied inferences. In each of the following imaginary exchanges, I think of the formative assessment as uncertain in form, a practitioner-bound embryo for putting theory-in-practice to practice and reflexively, location of disciplinary capability that transmit less of "micro-theories to institutional norms" (Argyris \& Schon, 1974, p. 157), and more to contextual purposes of the event, reembodied in reflection.

After initial resistance to the project that resulted in a lack of attendance and consequent getting together outside of the classroom. I employed embodied practices of consciously listening to the ways the students brought the result of their absence into the project talking about that at the beginning of a session. What restored their confidence in the hybrid setting was a reinvention of the 'spaces' around which they were enabled to prepare their assessment. Observing the presence of those attending and then feeding observations back to the students was a way of perceiving how students were already taking hold of collaborative learning. Pedagogical momentum, derived of consciously addressing issues of students in different places, positively affected achievement (Teacher journal, Tauhara, 2018).

In autoethnographic, reflexive mode, and as teachers adapting to the pace and place of online process, axiological shifts occur. In preference for subjectively enhanced modes of writing, Richardson (1994) declares that listening for an intuitive and embodied voice, even self-centred "should lead to writing that is more diverse, more author-centred, less boring, and humbler" ( $\mathrm{p}$. 524). While neither the imaginary letters nor the lesson reflections are empirical research per se, they give pause to think about the diversity of teaching process. For example, with a sense of critical reflexivity, a deconstruction of the latent interaction between teacher and technology, prompts a circuitous reflection about delivery mode. Although complex, and uncertainty is, through interactive livestream pedagogy, embodied values of clinical practice arise.

June 18, 2018

\section{Dear Mother}

I am writing to you about an article I started here at Tauhara - as you know I was recently handed a rather ambitious task of planning and implementing eLearning at the college -it's about having students in the classroom and in their homes or at a local library if there is internet there, at the same time. We use technology... I love the effort of that and how I must use multi senses to maintain focus, but I am finding the links between what I am teaching and managing technology precarious and daunting. It is what I am writing to you about and. what I want to write about is also challenging. I set myself a couple of tasks to get going.

One thing was to structure the process (of teaching and writing) a bit like a shopping list. The ways I start to see what happened, morphs as I go along, I am like that in the supermarket too. The thing is, and therefore I am writing to you as I know you will see things a little more clearly, you know me. I like tidying things up whether it is my desk or the living room-or in this case the college programmes. Teaching has always felt like practiced efficiency, and I was wondering if our teaching lately, has had to be fundamentally changed.

So, the next task is to write some of the memories of an assessment event that triggered the 'embryo' of my questions - something about how we make a good way of constructing andrecognising useful teaching? I like that plan because I have a feeling that the naturopathy programmes are caught in old pedagogy. Since being here, I have followed our old rule we have after teaching and I have been writing some reflections on the lessons. It is the uncovering of pedagogy that I want to write about. I wonder what that looks like? 
International Journal on Integrating Technology in Education (IJITE), Vol.10, No.4, December 2021

I know its early days, Mama, and uncertain but if possible, I want to capture 'uncovering' where the transfer from forbearance and muddliness of connecting to how the assessment outcomes happened. It is a formative assessment, brainstorming a research proposal. I asked one of my colleagues and she said she was excited at the early sophistication of the presentations. What if, in a somatic frame of reference - deep listening, awareness and breathing that supports me (and hopefully students) who are feeling anxious and uncertain is a practitioner mode that could become rooted in critical thinking and research education - and part of clinical practice?

June 20, 2018

\section{Dear Felicity}

You have such grand ideas about the world - take a breath, dear. Is the model of your thinking likely to change the way you teach; would it be something you could offer to students when they first started in the course? I am sure that you would expect resistance as a normal part of the course - is allaying student anxiety a way forward for teachers to recognise they might be anxious too? I think maybe this is really what you are writing for.

This response, as imaginary as it was, initiated a reflexivity and enabled a criticality fit for writing this research. What supports the reflexive nature of these two letters and their imagined responses is the mutuality of individuality and quieter revelations when reflecting on the role of a practitioner-educator. Wegerif (2015) illuminates what I mean by mutuality, as "an understanding of the role of technology with an understanding of the importance of maintaining different voices in tension" (p. 438). Deliberating teaching when utilising technology was an uncertain experience. The letters, full of inhibition and tension, reveal the potential of uncertainty, as increasing certainty within change pre-supposes that disciplinary approaches to technology are also in the throes of change.

\section{CONSTRUCTIVISM AT WORK IN A TRANS- OR INTERDISCIPLINARY CONTEXT}

Each theme, generated from the aim and the question is about how with eLearning, experienced practitioner-educators adapt to how to contribute to the discipline. To maintain the methodological impetus, critically informed comparisons are made between naturopathy and medical science education. Whether or not naturopathy education is like medical science education, evidence-based medical healthcare education is situated in neo-liberal contexts, and teaching is about encouraging students to become practitioners in professional occupation (Boud, 2021). Integration of education technology for progressing autonomous and agentic practitioners may be particularly challenging in emerging and specialist practice-based disciplines. Howsoever evidence-based practice requires applications of critical thinking skills and makes research relevant to clinical practice, links natural therapies educators make between teaching philosophy, experience, and practice are notably difficult to assess. I assume values-based complexities reveal holistic knowledge, and skills building that has its own lexicon of communication, assessment, planning and treatments.

Natural therapies education may be problematically lodged in traditional forms of healthcare education. Rather, turning away from traditional healthcare knowledge production to a transdisciplinary valuing of participation and practitioner experiencing offers new and differing ways of understanding bodies of knowledge and all on practice terms (Schmidt, \&Neuburger, 2017; Trott, Even, \& Frame, 2020). Insomuch as online delivery of a course previously taught face-to-face (F2F) occasioned "new approaches to learning [that] necessitate new approaches to 
teaching" (Hargreaves, 2003, p. 24), the New Zealand Qualifications Authority (NZQA) Level 5 critical thinking and research course is designed for first year students of an undergraduate degree.The formative assessment presented opportunity for engagement with the emerging discipline as autonomous and agentic of its own form of healthcare.

With a guest tutor present, the formative assessment took an unexpected turn. With her attention, I became aware I was registering teaching as though performing teaching. Garrison and Archer (2000) note, "construction of meaning may result from individual critical reflection, but ideas are generated, and knowledge constructed through the collaborative and confirmatory process of sustained dialogue within a critical community of learners" (p. 91). The formative as presentation offered chances to improvise and collaborate. In this way, the formative assessment became visible, and about transferable skills. On reflection, motivation revealed an embodiment discourse submerged within teaching practice.

The session started out in the same order as any other day: the flurry of last-minute planning and resources check; toing and froing as the F2F students arrived; a greeting for IT support and the returning Guest tutor, who self-selected to attend these first-year naturopathy formative presentations; a quick scrutiny of Off campus students' presence in the chat options box, water to hand, glance at the clock and away we went. I was nervous. (Teacher journal, Tauhara, 2018)

If research and critical thinking are embedded in an undergraduate curriculum early, the topics can become a feature of analytical and clinical reasoning. "Research-led: learning about current research in the discipline; and research-oriented: developing research skills and techniques" (Jenkins, \& Healey, 2010, p. 38) are focussed here on problem-solving the livestream setting and insights about transferable natural therapies clinical skills. The formative assessment is ordinarily used for teachers to gain information on the continuum of learning. If hybrid delivery is to fit within modes of educational sustainability prescribed by neoliberal imperatives of student numbers and qualification completions, there are other anomalies. During the assessment, reciprocated by instances of teacher adaptation, students took responsibility for complex problem solving, as integral to the formative experience. Advocates and critics of critical constructivist pedagogy believe that education systems on the one hand are influenced by social interaction and structures and, on the other hand, contribute to the status quo (Kincheloe, 2008; Richardson, 2003; Thompson, 2000). Questions that arise from perceptions that healthcare education destabilises alternative health sciences agendas and eLearning positively impacts the natural therapies' curriculum. I describe teacher (and students') openness to drift from long-standing methods of health knowledge dissemination as dialectic between and beyond the discipline (McGregor, 2015). Thus, the exchanges between teacher and students are not so much about exploring knowledge around or between natural therapies and other health modalities, but signification of a complex teaching self.

\subsection{Embodiment in disciplinary practice}

The willingness to embrace embodiment as a critical education position is what is novel. A delivery mode acquainted with clinical practice, and assessment, is inherent to practice applications (Boud, 2009; Walkington et al, 2011; Walkington, 2015). These authors explain how a sense of belonging is formed withina pedagogic approach that fits in eLearning. The integration of the topics is, on these terms, embodied, potent and transformative. Teacher perceptions about confusion that the students initially felt about the formative assessment as a measure of progress, is now compared with benefits for the students as they eventually engaged in collaborative activities. In addition, the experience of how the formative decentred assessment measuring and turned into collaboration surfaces the purpose of teaching online at all. 
Four weeks from the end of their second term, the first-year naturopathy students received the brief for the peer formative presentations: to brainstorm a research proposal. I requested that the pairs consisted of at least one F2F student and one off-campus student. In small groups of 2 or 3 , they chose a topic of shared interest, narrowed it in-class through a simple PICO process and sought literature that highlighted the direction their presentation might take. They were given a PowerPoint template with six slides and a selection of practicing research cards (Maidment, Chilvers, \& Crichton-Hill, 2012). Immediate resistance was apparent in the chat box and a F2F student reporting via email that the students were not happy that the proposal did not causally relate to a summative assessment. One student named the activity a research 'project' and another swore. (Teacher journal, Tauhara, 2018)

From the teacher perception, there existed an immediate strain between the formative intention of assessment, and engagement as it relates to other studies about practitioner-based pedagogy and critical education (Biesta, 2006; Clegg, 2008; McLaren, 2003; Peseta \& Grant, 2011; Shreeve, 2011; Ussher, \& Earl, 2010). hooks (2010) imposes a critical element for this discussion - what she names engaged pedagogy: "A teaching strategy that aims to restore students' will to think, and their will to be fully self-actualised.The central focus of engaged pedagogy is to enable students to think critically" (p. 8). Abednia and Izadinia (2013) depict a similar focus on a critically aware teaching strategy. This is locatable in another conception of student reaction: "They may even feel uncomfortable with a democratic atmosphere since they probably expect the teacher to give them a framework. Thus, teachers should provide students with ample opportunity to off-campus themselves from their traditional learning habits in due time" (p. 348). hooks' (2010) inferences add layer upon layer of intention that precludes the initial emotive reactions as more than relevant to the outcomes of the formative event: "Students [are] to be fully and compassionately engaged with learning, not ignoring the emotional feeling in the classroom" ( $p$. 8).

However, most students contacted their partner within the first day, and if they could not, negotiated with another student without a pair or a welcoming pair of students to join. More than one group named their topic within that same session. Through utilisation of the research cards, they discussed not only what natural therapies evidence-based proposal they wanted to draw on, but also presentation challenges they faced and other issues they knew to have to be surmounted in terms of regular communication and sharing of task load. By the end of the week and post a more immediate online Test, resistance tapered, and the wonderful co-construction of their proposal began. (Teacher journal, Tauhara, 2018)

Observable changes to mindsets, as the students' progressed together is a useful way of evaluating embodying mode, and the socialisation process was animated by their resilience in collaboration. Wall's (2006) cyclic orientation to reflexivity accommodates a participatory perspective, as though all of us (including the readers of this study) are momentarily caught in the co-constructed act of teaching. I perceived emotionally laden conflict that occurred in the first few days of the formative as transitional to recognising new ways of doing things, and what then became routine uncertainties of a critical thinking course emerge as adaptive mentality. In effect, these formative traits were pedagogic evidence and resource of practitioner sensibilities in-kind. The students gradually re-appeared online as partners in their formative assessment engagement, preparation and, through verbal and text-based communications, signifiers of pedagogical gaps in their content capabilities - signifiers of potential gaps discipline - also embodied. On these stated terms of communication, the themes of this article already "rebound with reflexivity" (Richardson, 2000, p. 8). In somathodological form, theories are there to resist any subversive motivation to measure guest tutor, student, or technician experience as one thing or another, or lead the reader to extrapolate the topic. I ponder disciplinary gaps in the following excerpt from my teaching journal. 
What was visible, student reactions to preparation and delivery, was my feeling for adaptive practice; practitioner-focussed, embodied teaching. I wanted the students to reach into their discipline with feeling of how they could work together with clients and colleagues in the future. Students' voices become murmurs of shared intention. The pace of prompts reminds me so much of our need to ensure the relevance of a scope of practice and our ability to professionally refer. The technician became another audience, effective in keeping our timing and operational issues out of sight in delivery. Constant reassurance was required. (Teaching journal, Tauhara, 2018)

By referring to all those present in the formative experience as participant with pedagogy, I focus the lesson reflections. They are already formed out of knowledge production in the discipline. A standpoint of "reflexivity is one in which the researcher pauses for a moment to think about how his or her presence, standpoint, or characteristics might have influenced the outcome of the research process" (Wall, 2006, p. 3). As I reflect on pedagogy in the process of writing, I am conscious of implicit dual engagement with reflexivity (Alvesson \&Sköldberg, 2009), of teaching, presence in observation mode and, how to regard experientialism-in-process. Evidencebase, which health practitioner's higher education and research trajectories is apprised, is debated as a de-enactment of naturopathy's constructivism. Selected theories provide space to discuss diffuse pedagogy about practice on embodied terms within glimpses of pedagogical intention and motivation. "A key question is how assessment practice can support the development of better collective as well as individual thinking" (Wegerif, 2015, p. 64). I take account of how the educational purpose was initially perceived by the teacher (and students) to be destabilised by technology rather than suggesting the topical and far-reaching purpose of the formative assessment.

\subsection{About transdisciplinarity: separating ideologies that natural healthcare suffers}

A subsequent comparison, of trans- and interdisciplinary standpoints highlights issues of assuming one healthcare paradigm fits all. Transdisciplinary work is supported by the following truisms: knowledge is complex and emergent and, there are various ways to accord real-life purpose (Nicolescu, 2008). However, pedagogical considerations hover between institutional expectations of successful graduation with biomedical education objectives, with an expectation that institutions and their graduates "can respond quickly and flexibly," (Hargreaves, 2003, p. 20) to public healthcare agendas. Contextualised by the article's themes, applications of embodiment to practitioner education, naturopathy education is not like medical science education. By theorising, a debate about the relevance of medical science education in neoliberal contexts is introduced. Practitioner embodied knowledge becomes a dissectible theme of necessary attributes if biomedical science education trajectories are assumed as effective and likely through hybrid learning. Considerations about embodied, and disembodied practice emerge.

In medical health contexts, with their distinguishing sociological and public health determinant characteristics of clinical practice, or biomedical research, may or may not be as relevant to the epistemologies of complementary healthcare modes (de Almeida Filho, 2001; WHO, 2010 \& 2019). According to the WHO Global Report (2010), "By 2012, the number of Member States providing high-level T\&CM education programmes including Bachelor, Master and Doctoral degrees at university level has increased from only a few to 39 , representing $30 \%$ of the surveyed countries" (p. 23). While education standards for clinical practitioners were implemented, I argue that autonomy and agency derived of natural therapies' collaborative and communicative clinical practices may have become diluted through conservative approaches to health education and pedagogy in what Bourdieu (1990, p. 73) describes as the "whole symbolically structured environment" - the academy, with its assorted "autonomy, prestige and privilege" (Hargreaves, 2000 , p. 219). Through the methodological process, and the $5^{\text {th }}$ narrative, I have come to regard 
International Journal on Integrating Technology in Education (IJITE), Vol.10, No.4, December 2021

challenges of naturopaths educated in a medical education context as interdisciplinary, rather than transdisciplinary.

\section{Hovering the Body Between Teaching and Embodied Practice}

Theories become filters to draw out my thinking: Questions of the body - the teacher's body, (and the students' bodies) are acutely relevant in the context of hybrid education, with some bodies being 'here' and others being 'there', and where technology becomes an essential third extension of the body, still in practice mode. For the body as an extension of technology in pedagogy, Mauss - exchange $(1966,1973)$, Bourdieu - habitus $(1977,1989)$ and Reckwitz's practice (2002a \& 2002b, 2012) contributions highlight the three assumptions of pedagogy that are relevant to the article.

Embodied teaching is an entry point to articulating hybrid practice-based education's coherence with natural health clinical practice, but not necessarily with medical health' education purpose. What is significant to this exploratory process is how practitioner attributes of self-awareness, including breathing and listening in cognitive and embodied modes can become the invisible effects of a practice-based discipline. In turn, by deconstructing a new hybrid learning process recentres natural therapies' practitioner habitus, which may be a necessary move towards articulating a more specific realm of healthcare, identity, and integration.

June23, 2018

\section{Dear Dad}

I am at a stage on my writing that I think needs to find a bridge.The explanations about the college coming into blended delivery are all there - and it is easy enough to describe the formative event. That is the example of co-construction - or as I am also describing it experiencing hybridity. I want to use the somatic methodology that I used in my thesis as it seems fitting this time round. I can feel developing links between the moment-by-moment experience of watching the students and experiencing teaching. That reminds me of the experiential - what do I mean by that - I can hear you say it already? By experiential - I remember that more than one student expressed strong resistance with her online comments about the idea of doing a project that required work not related to a summative assessment, and that the effort to connect via $F B$ and WhatsApp was more than they could be bothered with. I think in her questioning and assuming everyone felt the same way that the students experienced something quite profoundapplicable to their discipline, although I do not know if it was them all that experienced it maybe they felt a gratifying flow, their ideas in early fruition mode. I think it was more that I as teacher experienced something, in observation.

June 25,218

\section{Dear Felicity}

It sounds from what you are writing here is that the reaction to an assessment you describe is not uncommon - from my experience as a professor at the university, students are always somewhat resistant to assessment - certainly, activities that are unclear as to their connection to an obvious learning objective. As always, I find your meandering approach to teaching unusual. As you know, I lectured in vast halls where students' faces were something of a blur. Needless to say, I met these students once they were in the hospital with me on the rounds and I could remember their questions, some of them verging on conflicted - their training with how they really wanted to be. Similarly, I can see you tracking the students to practitioner experience. I did that through 
remembering and revisiting their questions in clinical mode. It is more like you claim a sort of quieter voice about teaching - an observational voice to write with and you have the means to do just that. With your somatic approach - as you have told me before - it is about support for the sensing body in teaching for the profession. By the way I really like it that you are wondering if this listening, awareness, and support of education in practitioner mode. That was not something we did in my time. We did learn about empathy though.

Teaching supported by practitioner knowhow and motivation will mean that teachers enact more than readiness for teaching, if they practice their body in class, without disregarding what "does not fit in with the unified image that we present to ourselves and others" (Haug, 2016, p. 226). In the first letter, I focus less on issues surrounding academic meaning-making and more on perceived tensions when developing interactions through self-observations. Haraway's (1991) notions of feminism, "particularly its emphasis on identity, rather than affinity" (p. 32) situates my uneasy academic concerns as integrated acts of subversion. That is, academia is not our real world; teaching clinical practice still is.

\section{IDENTITY AS THOUgh 'IT' - 'THE TEACHER's BODY’ WAS ABSENT}

Rather than, finding teaching and managing technology precarious and daunting, if technology is to be regarded as catalysing, the body shifts into alternative spaces of teaching, more than I described previously as managing classrooms and access. It was the 'good' communication that facilitated the specificity of learning needs, and by extension teaching in the throes of technology is registered by subjectively noticing that livestream tasks inform transferable practice skills. Teacher practice and practitioner identity are, therefore, considered within the realms of a conscious, organised, 'social presence' (Swan, Garrison \& Richardson, 2009). If technology is to be regarded as catalysing, and not just 'another alternative remedy but as repositioning us in the practitioner education discourse, the body shifts into alternative space of teaching. The teacher's body registering is generated by the internal 'environment' of the body, inevitably through gesture and intention and transmitted to the external.

The external may seem the content material, but on Haug's (2016) terms of hope, the teacher (and students) bodies, brains, and minds are present and simultaneously external; environments catalysed into knowingness by technology in the interactive classroom. Yet, the body is still three-dimensional, dynamic, and spatial, environment of embodied practice. That is how we come to use multi senses to maintain focus and as active ways of recognising productive absence congruent with spatially informed bodies in practice (Leder, 1990; Lepecki, 2004; Noland, 2009. On my prior journal reflection, I thought about how I listened to the ways the students navigated their absence, bringing their consequential attendance into the project by talking about that at the beginning of a session. This became a useful transitioning period. Baseline themes that arose out of theorising about practitioner presence-of-mind in classroom communication, may then be described as critical to 'presence' and 'absence' in integrative clinical education, where students and inevitably clients may be more able to attend consciously when less physically in clinic spaces. Multi-sensing could become a model of practitioner eLearning and something we as teachers offer to students when they first start in a course.

Conscious organisation and adaptation are enacting the threshold of knowers claim to knowing. The absence of the body is what we are used to as in "being-away" (Leder, 1990, p. 173). As mentioned in the journal excerpt, I want the students to reach into their discipline with feeling of how they could work together with clients and colleagues in the future. Leder writes of a body "ontologically identified with sheer presence. It is an object with clearly defined location and boundaries, here, not there, enclosed within itself" (ibid). It is as if being the teacher is less likely to be viewed as a knower (a brain) rather they become the 'body' of knowledge and 
understanding. The 'sheer' nature of the non-present body teaching is what is interacting through technology (Holton, 2010; Maturana\& Varela, 1987). I am sure in these ways of understanding presence and absence; we can expect and navigate resistance.

Methodologically speaking, journaling, letters and theories develop reflexive responses to practitioner-educator pedagogy - and they can be re-positioned as present or absent as embodied, conscious, and experiencing. Keeping in mind, experience comes through enhancement of the senses. By sensing and experiencing, I mean the attuned organising attention that is "based on listening to non-verbal cues arising from breath, touch, and movement" (Batson, 2009, p. 2). "Take a breath, dear," my Mother wrote. What if, in a somatic frame of reference - something I reflected on as a familiar, performance shyness supports me and students transitioning. What if, deep listening, awareness and breathing when both of us feel anxious and uncertain, is a formative practitioner mode that could become rooted in critical thinking and research education - and part of clinical practice? This kind of teaching presence is experientialism's cognition or, on Maturana and Varela's (1987) terms, the phenomenon of knowing.

\subsection{Identity and the profession}

Despite the lack of global professionalisation, regulation or education consistency or standards, students gain natural therapies qualifications through conventional healthcare education methods. In 2010, World Health Organisation (WHO) developed a series of benchmark documents to ensure that TM/CAM tertiary education met the minimum adequacy of professional knowledge, skills and attributes required for practice. They are still being written. Moreover, knowledge acquisition and attributes of the biomedical science profession was recently assumed as effective and likely through hybrid learning (Hargreaves, 2000; Jiménez-Saiz\& Rosace, 2019). Pedagogies, hovering between institutional expectations of successful graduation within biomedical education objectives and are expected to "respond quickly and flexibly," (Hargreaves, 2003, p. 20) - to the eLearning environment, as much as through the physical environment of face-to-face learning. What works for nurses, midwives, and osteopaths for example, may need rethinking in the perspectives of the holistic patient-centred care. In the meantime, natural therapies practitioners are not regulated to deliver integrated, patient-centred care in the medical system (Hunter, Wardle, Kotsirilos, Molodysky\& Ewer, 2016; Leidl, Ritchie, \&Moslemi, 2020).

In context with WHO' priority about integration, a question of identity arises - about how practitioner-educators advance natural therapies concepts through eLearning in tertiary education. In health science evidence-based contexts, this problem may be more about whether, as Bourdieu (1990) describes: "The essential part of the modus operandi that defines practical is transmitted through practice" (p. 73). I noticed how as, 'resistance tapered', that a 'wonderful co-construction of their proposal began'. I argue that experience can become educationally discernible if derived of relevant practice attributes. While many natural therapies educators have prior or ongoing experience as clinical practitioners, how they work within tertiary education contexts may be as specialists reliant on content driven outcomes. These prompts are described by Segrave and Holt (2003), as requiring design and analysis that underscore contexts for learning the profession in question, and enablement.

\section{Practice Values Enhanced by Critical Thinking}

Livestream classrooms are already fluid learning environments. That is, they have within them products of a vanishing world, of primarily onsite learning. A world to be reinvented by noticing change. Mauss $(1966 ; 1973)$ writes about technologies of the body and intuitive exchanges that occur thereof, as a gift. I get a sense that Mauss' writing is informed by practice understandings - 
of posture, gesture, flow, pace, and timing. These are aspects that affect practice skills, not to be lost in this critical era of educational flux and change. I had described this as pedagogical momentum, derived of consciously addressing issues of students in different places. I noted how this momentum, even in the time of flux, positively affected achievement. Bourdieu is correct in that embodied experience in social space results in "substantialism" - where interactions provide more than is expected of their initial intention $(1989$, p. 16). Howsoever practitioner attributes in interactive livestream spaces, content driven curriculum accommodates learning that contributes to the formation of dispositions and practices that are adaptive for clinical practice (Bourdieu, 1977; Kelly, Ellaway, Scherpbier, King, \& Dornan, 2019). Practice theorist, Reckwitz (2002a, 2002b, 2012) recurrently debates ways that space affects practice. He states how seeing the body in alternative spaces places practice. As with Bourdieu, in Reckwitz' theories of practice, the body once transcribed as teaching becomes problematic, only if made symbolic of aforementioned conservative methods for teaching healthcare.

The impetus for noticing while teaching becomes interconnected as bodily and mental behaviour, reliant now on "motivational knowledge" (Reckwitz, 2002b, p. 249). In the letters, I expand notions of pedagogy to the visceral and organic, of body systems - respiratory and nervous systems practices that are alert to teaching presence with an extension to clinical practicing. Conscious cognition and adaptation theories of Maturana and Varela (1987) support the inclusion of 'presence' as a theorisable sub-theme. The teacher's body, enactive of the apprehension and comprehension of practice, is now a body that expresses information as periphery. I was pleased that one of my colleagues, one of the 'old pedagogy' too, said that she was excited at the early sophistication of the presentations. The content and the presentation skills were there. Practitioner communication is therefore reflective and what the educator knows that is not just there to be enclosed within self. Teachers are not as: "mere 'instrument' but routinized and agentic" (Reckwitz (2002a, p. 251). What I have assumed as agentic is that the body is instrumental in processual, educational practice. That is, the profession's identity may be significantly affected in critical shifts between teaching from practitioner-knowledge bases and broader, value-laden contexts of the academy.

If I am to regard the teacher's body - a practitioner educator - at all, in active apprehension of practice mentality, the focus is on practice attributes that are of socio-individual perception, rather than formed out of the socio-educational imperatives of a national qualification. If I am to regard socialised presence in the critical thinking component of the livestream course, the formative assessment became locus for clinical practice pedagogy (Borton, 1970; Swan, Garrison \& Richardson, 2009). Clinical practice as an embodied form is already considered. Experiential modes revalue aspirations for emergent practitioner identities. In readiness for natural therapies as embodied work, active images of the teacher as clinical practitioner are called to mind. Furthermore, socialised critical thinking as an embodied form of learning exists already within the mode of student aspiration. The practicality of these emergent samples connects to the kind of practitioner identity I am writing about.

F2F and off-campus students, even when learning in a disembodied electronic place, become hands-on practitioners in clinical settings. Clinical practice requires an embodied sense of immediacy and presence. Teaching with technology requires an adaptable approach to the pace of practice transformation. On terms of practice, productive engagement with the teacher in her disposition of practitioner is equivalent to dynamic learning exchange - of changes to the agentic through embodied practice, to educational transformation and change (Bourdieu, 1989; Gikandi, Morrow \& Davis, 2011; Noland, 2009; Somerville, Davies, Power, Gannon \& de Carteret, 2011). Lepecki (2004) devolves kinaesthetic connections to practice disciplines and, on somatic terms of reference, places value on systematic embodied approaches to an intellectual life. 


\section{Summary: New Routines of 'Body' in Clinical Practice EDUCATION}

A range of insights from the somatic narrative and pedagogical responses to the formative has occurred. The autoethnographic narrative revealed the rapid implementation of practitioner sensibilities to adapt to livestream classrooms and opens doors to educator resources. The rapidity of online implementation may have produced an unusual set of perspectives that focus online engagement on embodying practice consistency in critical thinking and research practice. As a result of these reflections, I have since introduced new routines, mindfulness activities at the commencement of each livestream session. This is to activate postural awareness and new kinaesthetic habits. I now regularly include somatic breathing practices to transition student bodies into a parasympathetic nervous system response for their sense of presence, focus and receptivity. My intention is to incrementally displace disembodied practices of bodies in the classroom and reconsider computer stations as fluid spaces. The aim is to provide resources for students to know how to settle into any dynamic postural placement, classroom, and clinic.

Livestream classroom activities and socialisation processes are bound to maintain outcomes of student retention, achievement, and graduate capabilities (Evans,Muijs,\&Tomlinson, 2015). It is just as important to establish an ethos for autonomous learning that entails engagement on practice terms with students in critical process. Natural therapies education requires future focussed on conventional topics that relate to their specific modes of healthcare. Online teaching has resources that align natural therapies as practice-based and an embodied discipline. In the integrative healthcare context, livestream teaching and learning may provide opportunities to develop adaptive clinical behaviour and in time, the formation of embodying practitioner habitus. Students, with their assumptions about natural therapies' trends and applications, require critical thinking and familiarity with their own kinds of practice concerns, what I have termed experiencing hybridity. The online learning community forms a social (and clinical) presence yet, so far, there is no explicit framework for natural therapies educators to take account of practice relationships between on- and off campus environments, or for processing of this experiential milieu. While the natural healthcare profession is not yet regulated by globally recognised standards, in the education context, embodied pedagogy enables the exchange of emergent knowledge to the new collective, directly in keeping with natural therapies principles and clinical practice.

Curriculum delivery must ensure social practices of embodiment, kinaesthetic dialogue, and collaboration. Group-based projects require reassurance and support. In keeping with global agendas for integrative care to be societally accessible, embodied practice is a critical means of professionalism. In somatic context, online process may be regarded as experiential locus with precious and embodied insights available to guide institutional imperatives. In summary, I identify several transdisciplinary opportunities for future research. They are about yet unarticulated topics of physical and kinaesthetic knowledge in all healthcare education. The purpose of drawing on theories was to regard issues the initial question raised, while exploring embodied elements of clinical practitioner pedagogy. On Bourdieu's (1990) terms, resolving technological and communication challenges are recognisable as features of embodied practice. For example, the catalysing effect of a colleague observing the formative presentations that provoked student resistance, once articulated as critical constructed learning in a changing learning environment, is subsequently relatable as evolving practice attributes (in a most practical state and most relevant to naturopathy). Furthermore, the student who questioned the relevance of the formative assessment found in her responses 'something quite profound - applicable to the discipline, although it is true (as this article is not the students' account), I do not know if it was all of them that experienced it. Meeting technological obstacles with patience and enquiry 
International Journal on Integrating Technology in Education (IJITE), Vol.10, No.4, December 2021

accumulate as natural therapies' capital, - a gratifying flow, a new generation of learning in early fruition mode. In hindsight the use of technology was fluidly vested back into naturopathy practitioner curriculum, a pedagogy freshly enhanced with eLearning.

\section{REFERENCES}

[1] Abednia, A., \& Izadinia, M. (2013) Critical pedagogy in ELT classroom: Exploring contributions of critical literacy to learners' critical consciousness, Language Awareness, 22(4), 338-352, doi: $10.1080 / 09658416.2012 .733400$

[2] Acolin, J. (2019). Towards a clinical theory of embodiment. In H. Payne, S. Koch, J. Tantia, \& T. Fuchs (Eds.), The Routledge international handbook of embodied perspectives in psychotherapy, approaches from dance movement and body psychotherapies (pp. 40-52). Routledge.

[3] Alvesson, M., \& Sköldberg, K. (2009). Reflexive methodology: New vistas for qualitative research ( $2^{\text {nd }}$ ed.). London, England: Sage.

[4] Argyris, C., \& Schon, D. (1974). Theory in practice: Increasing professional effectiveness. San Francisco CA: Jossey Bass.

[5] Batson, G. (2009). Somatic studies and dance. [Resource paper]. Education Committee of the International Association for Dance Medicine and Science (IADMS). Retrieved from https://www.iadms.org/page/248

[6] Bell, D., Canham, H., Dutta, U., \& Fernández, J. S. (2020). Retrospective autoethnographies: A call for decolonial imaginings for the new university. Qualitative Inquiry, 26(7), 849859. https://doi.org/10.1177/1077800419857743

[7] Biesta,G. J. (2006). Beyondlearning: Democraticeducationforahumanfuture. Boulder,CO: Paradigm. doi: $10.4324 / 9781315635811$

[8] Borton, T. (1970). Reach teach and touch. Student concerns and process education. London, England: McGraw Hill.

[9] Bourdieu, P. (1977). Outline of a theory of practice. R. Nice (Trans.). Cambridge, England: Cambridge University Press.

[10] Bourdieu, P. (1989). Social space and symbolic power. Sociological Theory, 7(1), 14-25. doi: $10.2307 / 202060$

[11] Bourdieu, P. (1990). Logic of practice. R. Nice (Trans.). Stanford, CA: Stanford University Press.

[12] Claussen, S., \& Osborne, J. (2013). Bourdieu's notion of cultural capital and its implications for the science curriculum. Science Education 97(1), 58-79. https://doi.org/10.1002/sce.21040

[13] Clegg, S. (2008). Academic identities under threat? British Educational Research Journal, 34: 329345. doi:10.1080/01411920701532269

[14] de Almeida Filho, N. (2001). For a general theory of health: Preliminary epistemological and anthropological notes. Cad Saude Publica, 4:753-70; discussion 771-99. doi: 10.1590/s0102$311 \times 2001000400002$.

[15] Denzin, N. K. (2013). The death of data? Cultural Studies $\leftrightarrow$ Critical Methodologies, 13(4) 353- 356. doi:10.1177/1532708613487882

[16] Eddy, M. H. (2002). Dance and somatic inquiry in studios and community dance programs. Journal of Dance Education, 2, 119-127.

[17] Ellis, C., Adams, T. E. \& Bochner, A. P. (2010). Autoethnography: An Overview [40 paragraphs]. Forum Qualitative Sozialforschung / Forum: Qualitative Social Research, 12(1), Art. 10, http://nbn-resolving.de/urn:nbn:de:0114-fqs1101108.

[18] Evans, C, Muijs, D., \& Tomlinson, M. (2015). Engaged student learning: High-impact strategies to enhance student achievement. York, England: Higher Education Academy. Accessedathttps://www. heacademy.ac.uk/sites/default/files/engaged_student_learning_high-impact_pedagogies.pdf

[19] Garrison, D. R., \& Archer, W. (2000). A transactional perspective on teaching and learning: A framework for adult and higher education. Oxford, England: Pergamon.

[20] Gikandi, J. W., Morrow, D., \& Davis, N. E. (2011). Online formative assessment in higher education: A review of the literature. Computers \& Education, 57(2011), 2333-2351. doi:10.1016/j.compedu.2011.06.0 04

[21] Ginot, I., Barlow, A., \& Franko, M. (2010). from Shusterman's so aesthetics to a radical epistemology of somatics. Dance Research Journal, 42(1): 12-29. https://doi.org/10.1080/15290824.2002.10387220 
International Journal on Integrating Technology in Education (IJITE), Vol.10, No.4, December 2021

[22] Grant, B., \& Knowles, S. (2004). Flights of imagination: academic women be(com)ing writers. In M. Tight (Ed.), The RoutledgeFalmer Reader in Higher Education (pp. 232-247). New York, NY: RoutledgeFalmer.

[23] Green, B. N., \& Johnson, C. D. (2015). Interprofessional collaboration in research, education, and clinical practice: working together for a better future. The Journal of Chiropractic Education, 29(1), 1-10. https://doi.org/10.7899/JCE-14-36

[24] Hargreaves, A. (2003). Teaching in the knowledge society: Education in the age of insecurity. New York, NY: Teachers College Press.

[25] Hargreaves, D. H. (2000). The production, mediation and use of professional knowledge among teachers and doctors: A comparative analysis. In Knowledge Management in the Learning Society (pp. 219-236), Organisation for Economic Co-Operation and Development (OECD): Paris, France. https://doi.org/10.1787/9789264181045-en.

[26] Haug, F. (2016). The politics of hope: Memory work as a method to study the conduct of everyday life. In Schraube, E., \&Højholt, C. (Eds.), Psychology and the Conduct of Everyday Life (226-240). Hove, England: Routledge.

[27] Holton, D. (2010). Constructivism + Embodied Cognition = Enactivism: Theoretical and Practical Implications for Conceptual Change. Paper presented at the American Educational Research Association (AERA), 30 April-4 May, Denver, CO. Accessed at http://usu.academia.edu/ edtechdev/Papers/168218/Constructivism_Embodied_Cognition_Enactivism_Theoretical_and_Practi cal_Implications_for_Conceptual_Change

[28] hooks,b. (2010). Teachingcriticalthinking: Practicalwisdom. NewYork,NY: Routledge.

[29] Hunter. J., Wardle, J., Kotsirilos, V., Molodysky, E., \& Tim Ewer, T. (2016). The case for establishing an Australasian integrative medicine practice-based research network. Australian Family Physician, 45(12), 925-927.

[30] Jenkins, A. \& Healey, M. (2010). Undergraduate research and international initiatives to link teaching and research. Council on Undergraduate Research Quarterly, 30(3), 36-42. Retrieved from https://www.cur.org/assets/1/23/303-36-42.pdf

[31] Kelly, M., Ellaway, R., Scherpbier, A., King, N., \& Dornan, T. (2019). Body pedagogics: Embodied learning for the health professions. Medical Education, 53(10), 967-977 https://doi.org/10.1111/medu.13916

[32] Kim, H., Sefcik, J. S., \&Bradway, C. (2017). Characteristics of Qualitative Descriptive Studies: A Systematic Review. Research in Nursing \& Health, 40(1), 23-42. https://doi.org/10.1002/nur.21768

[33] Kincheloe, J. L. (2008). Critical pedagogy primer. New York, NY: Peter Lang.

[34] Koch, S. C. (2014). Rhythm is it: Effects of dynamic body feedback on affect and attitudes. Frontiers of Psychology, 5, 537. doi: 10.3389/fpsyg.2014.00537

[35] Kusters, I. S., Gregory, M. E., Bryan, J. L., Hysong, S. J., Woodard, L. D., Naik, A. D., \& Godwin, K. M. (2020). Development of a hybrid, interprofessional, interactive quality improvement curriculum as a model for continuing professional development. Journal of Medical Education and Curricular Development, 7, 2382120520930778. https://doi.org/10.1177/2382120520930778

[36] Larson, M. S. (1977). The rise of professionalism: A sociological analysis. Berkeley, CA: University of California Press.

[37] Leder, D. (1990). The absent body. Chicago, IL: The University of Chicago Press.

[38] Leidl, D. M., Ritchie, L., \& Moslemi, N. (2020). Blended learning in undergraduate nursing education - A scoping review. Nurse Education Today, 86, 104318. https://doi.org/10.1016/j.nedt.2019.104318

[39] Lepecki, A. (2004). Of the presence of the body: Essays on dance and performance theory. Middletown, CT: Wesleyan University Press.

[40] MacLure, M. (2006). The bone in the throat: Some uncertain thoughts on baroque method. International Journal of Qualitative Studies in Education, 19, 729-746. https://doi.org/10.1080/09518390600975958

[41] Maidment, J., Chilvers, D., \& Crichton-Hill, Y. (2012). Practicing research cards. Christchurch Polytechnic Institute of Technology; University of Canterbury, Christchurch, NZ: AKO Aotearoa. Accessed at https://ako.ac.nz/assets/Knowledge-centre/RHPF-s1015-collaborative-fieldresearch/RESOURCE-Practising-Research-Cards.pdf

[42] Martin, M. G. F. (1993). Sense modalities and spatial properties. In N. Eilan, R. McCarty, \& B. Brewer (Eds.), Spatial representations: Problems in philosophy and psychology (pp. 206-218). Oxford, England: Oxford University Press. 
International Journal on Integrating Technology in Education (IJITE), Vol.10, No.4, December 2021

[43] Maturana, H. R., \& Varela, F. J. (1987). The tree of knowledge: The biological roots of human understanding. Boston, MA: Shambhala.

[44] Mauss, M. (1966). The gift: Forms and functions of exchange in archaic societies. (I. Cunningson Trans.). London, England: Cohen \& West. (Original work published 1950).

[45] Mauss, M. (1973) Techniques of the body. Economy and Society, 2(1), 70-88. doi: $10.1080 / 03085147300000003$

[46] McGregor, S. L. T. (2015). Transdisciplinary knowledge creation. In P. Gibbs (Ed.), Transdisciplinary professional learning and practice (pp. 9-25). Cham, Switzerland: Springer.

[47] McLaren,P. (2003). Criticalpedagogy: Alookatthemajorconcepts. InA. Darder, M. Baltodano, \& R.D. Torres (Eds.), Critical Pedagogy Reader (pp. 69-96). New York, NY: Routledge Falmer.

[48] Molloy, F. (2016). Fit to teach: Tracing embodied methodologies of dancers who come to academia. (Doctoral dissertation, University of Auckland, Auckland, New Zealand). Retrieved from http://hdl.handle.net/2292/34441

[49] Molloy, F. (2021). The emergence of somathodology: Sharing the dancing bricoleur. Academia Letters, Article 3423. https://doi.org/10.20935/AL3423.

[50] Morgan,C. \&Bird,J. (2007). Flexibleassessment: Sometensionsandsolutions. InB. H. Khan (Ed.),Flexiblelearninginaninformationsociety (pp. 247-260). Hershey,PA: InformationScience.

[51] Nguyen, D.J., Larson, J.B. (2105). Don't forget about the body: Exploring the curricular possibilities of embodied pedagogy. Innovative Higher Education, 40, 331-344 (2015). https://doi.org/10.1007/s10755-015-9319-6

[52] Nicolescu, B. (2008). Transdisciplinarity: Theory and practice. Cresskill, NJ: Hampton Press.

[53] Noland, C. (2009). Agency and embodiment: Performing gestures/producing culture. Cambridge, MA: Harvard University Press.

[54] Paul, G., Elam, B., \& Verhulst, S. J. (2007). A longitudinal study of students' perceptions of using deep breathing meditation to reduce testing stress. Teaching and Learning in Medicine 19(3), 287292. doi: 10.1080/10401330701366754

[55] Peseta, T. \& Grant, B. (2011). Working imaginatively with/ in contradiction. International Journal for Academic Development, 16(1), 1-4, doi: 10.1080/1360144X.2011.546207

[56] Reckwitz, A. (2002a). Toward a theory of social practices: A development in culturist theorizing. European Journal of Social Theory, 5(2), 243-263. doi:10.1177/13684310222225432

[57] Reckwitz, A. (2002b). The status of the "material" in theories of culture: From "social structure" to "artefacts". Journal for the Theory of Social Behaviour, 32(2), 195-217. doi:10.1111/14685914.00183

[58] Reckwitz, A. (2012). Affective spaces: A praxeological outlook. Rethinking History: The Journal of Theory and Practice, 16(2), 241-258. doi:10.1080/13642529.2012.681193

[59] Richardson, L. (1997). Felds of play. Constructing an academic life. New Brunswick, NJ: Rutgers University Press.

[60] Richardson, L. (2000). New writing practices in qualitative research. Sociology of Sport Journal, 17(1), 5-20. doi: https://doi.org/10.1123/ssj.17.1.5

[61] Richardson, V. (2003). Constructivist pedagogy. Teachers College Record 105(9), 16231640. https://doi.org/10.1046/j.1467-9620.2003.00303.x

[62] Sandelowski, M. (2010). What's in a name? Qualitative description revisited. Research in Nursing \& Health, 33(1), 77-84. doi: 10.1002/nur.20362. PMID: 20014004.

[63] Schmidt, L., \& Neuburger. M. (2017). Trapped between privileges and precariousness: Tracing transdisciplinary research in a postcolonial setting. Futures. 93, 54-67. https://doi.org/10.1016/j.futures.2017.07.005.

[64] Segrave, S., \& Holt, D. (2003). Contemporary learning environments: Designing e-learning for education in the professions. Distance Education, 24(1), 7-24, DOI: 10.1080/01587910303044

[65] Shor,I. (1996). Whenstudentshavepower. Negotiatingauthorityinacriticalpedagogy. Chicago,IL: TheUniversityofChicagoPress.

[66] Shreeve, A. (2011) Being in two camps: Conflicting experiences for practice-based academics. Studies in Continuing Education, 33(1), 79-91. doi:10.1080/0158037X.2011.521681

[67] Somerville, M., Davies, B., Power, K., Gannon, S., \& de Carteret, P. (2011). Place Pedagogy Change (Transgressions: Cultural Studies and Education). Rotterdam, Netherlands: Sense.

[68] Swan, K., Garrison, D. R. \& Richardson, J. C. (2009). A constructivist approach to online learning: The community of inquiry framework. In Payne, C. R. (Ed.), Information technology and 
International Journal on Integrating Technology in Education (IJITE), Vol.10, No.4, December 2021

constructivism in higher education: Progressive learning frameworks (pp. 43-57). Hershey, PA: IGI Global.

[69] Thompson, P. (2000). Radical constructivism: Reflections and directions. In L. P. Steffe, \& P. W. Thompson (Eds.), Radical constructivism in action: Building on the pioneering work of Ernst Glaserfeld (pp. 412-448). London, England: Falmer Press.

[70] Tihanyi, B. T., Ferentzi, E., \& Köteles, F. (2017). Characteristics of attention-related body sensations. Temporal stability and associations with measures of body focus, affect, sustained attention, and heart rate variability. Somatosensory \& Motor Research, 34(3), 179-184. https://doi.org/10.1080/08990220.2017.1384720

[71] Trott, C.D., Even, T.L. \& Frame, S.M. (2020). Merging the arts and sciences for collaborative sustainability action: a methodological framework. Sustainable Science, 15, 1067-1085. https://doi.org/10.1007/s11625-020-00798-7

[72] Ussher, B. \& Earl, K. (2010). 'Summative' and 'formative': Confused by the assessment terms? New Zealand Journal of Teachers' Work, 7(1), 53-63. Retrieved from https://researchcommons.waikato.ac.nz/handle/10289/4845

[73] Walkington, H. (2015). Students as researchers: Supporting undergraduate research in the discipline in higher education. higher education academy. Retrieved from https://www.heacademy.ac.uk/system/files/resources/Students\%20as\%20researchers_1.pdf

[74] Walkington, H., Griffin, A. L., Keys-Mathews, L., Metoyer, S., Miller, W., Baker, R., \& France, D. (2011). Embedding research-based learning early in the undergraduate geography curriculum. Journal of Geography in Higher Education 35(3), 315-330. doi: https://doi.org/10.1080/03098265.2011.563377

[75] Wall, S. (2006). An autoethnography on learning about autoethnography. International Journal of Qualitative Methods 5(2), 146-160. Retrieved from http://citeseerx.ist.psu.edu/viewdoc/download?doi=10.1.1.491.9506\&rep=rep1\&type=pdf

[76] Wegerif, R. (2015). Technologyandteachingthinking; whyadialogicapproachisneededforthetwentyfirstcentury. InR. Wegerif, J. Kauffman,\&L. Liu (Eds.), Handbook of research onteachingthinking, (pp. 427-440). London,England: Routledge.

[77] WHO Global Report on Traditional and Complementary Medicine (2019). Geneva, Switzerland: World Health Organization. Licence: CC BY-NC-SA 3.0 IGO. Accessed at https://www.who.int/traditional-complementary-integrativemedicine/WhoGlobalReportOnTraditionalAndComplementaryMedicine2019.pdf?ua=1

[78] World Health Organization. (2010). Benchmarks for training in traditional / complementary and alternative medicine: benchmarks for training in naturopathy. World Health Organization. https://apps.who.int/iris/handle/10665/44355

\section{AUTHOR BIOGRAPHY}

Felicity Molloy PhD, MEd, GDHE, MNZ RMT, YogaNZ Council, REPs, Victorian College of Arts (Dip. Dance) is an experienced practitioner-educator with extensive project and academic experience from administration to strategic development of community and tertiary education programmes in emerging fields of dance, older adult's wellbeing, and natural therapies. Outstanding award for a PhD dissertation received from AERA Qualitative Research SIG 2018, Fit to Teach: Tracing Embodied Methodologies of Dancers Who Come to Academia, bringing interdisciplinary practice-based skills to every project she undertakes. Currently an independent academic developing nutritional programmes for a naturopathy college. Co-author of Dance mobility: a somatic and dance programme for older adults in New Zealand (2015), with researchers Keogh, J., Krampe, J., \& Guzmán. 